\title{
Mainstreaming of climate change risks security through mitigation and adaptation strategies in Nepal
}

\section{Pashupati Nepal}

\begin{abstract}
A combined effect of high mountains and highly concentrated monsoon rainfall and socio-economic conditions make Nepal a highly vulnerable country to climate change. Whereas Nepal barely shares emissions of Global Greenhouse Gases (0.027\%), it is the fourth most vulnerable country in the world due to the effects of climate change. In this context, this paper aims to review the National Climate Change Policy, 2019 to identify the mainstreaming of mitigation and adaptation strategies in response to the climate change for different sectors and cross cutting sectors. Such an important policy document has for the first-time addressed climate change mitigation and adaptation strategies for different sectors and cross-cutting sectors. It has made provision of institutional set-up representing federal, provincial and local levels. Some of the new strategies under this policy include development and expansion of 'payment for ecosystem services', construct pond to collect rain water, make cycle lane in urban roads, increase carbon stocks, and use renewable technologies and manage climate finance. It has given sole responsibilities of functional coordination to the Ministry of Forest and Environment (MoFE) leaving other ministries as passive partners. This can create incoherence between and among the ministries and departments. The policy formulation and institutional set-up need to be complemented by legislation to achieve
\end{abstract}

expected out-puts. Until now, there is not a single legal document in Nepal that exclusively addresses the climate change issue. Therefore, promulgation of Climate Change Act 2019 can resolve the problems of climate change in the spirit of this policy.

Keywords: climate change, greenhouse gas, adaption strategies,

\section{Introduction}

Rapid increase in earth's surface temperature and changing precipitation pattern has resulted in direct implication to multiple sectors. A combined effect of high mountains and highly concentrated monsoon rainfall and socio-economic conditions (ranks 149 in 2017 on the Human Development Index, merely one-fourth of its population live below poverty line) make Nepal a highly vulnerable country to climate change. Nepal's geography makes the country's climate particularly complex. Because of the extreme variations in elevation within short distances, Nepal's climate varies significantly across the country, ranging from alpine and arctic in the north to tropical in the south. The country experiences tropical, meso-thermal, micro-thermal, taiga and tundra types of climate. Nepal has experienced direct impacts of climate change and is one of the most vulnerable countries to climate change in the world (CBS, 2017). Nepal barely shares emissions of Global Greenhouse Gases with $0.027 \%$ of global greenhouse gas emission 
(MoPE, 2016b), it has been facing severely adverse climate change effects. Nepal is the fourth most vulnerable country with climate change effects (MoSTE, 2015) resulted from an increasing level of temperature and change in precipitation patterns in different sectors, including agriculture, forest, water resources and disaster (MoPE, 2016a). The emerging climate status of Nepal demands integration of climate change adaptation into various sectoral policies/plans and programs so that people can adapt to the changing situation (NPC, 2011).

Recent study on observed climate trend analysis from 1971 to 2014 by the Department of Hydrology and Meteorology (DHM) shows that the average annual maximum temperature has been increasing by $0.056^{\circ} \mathrm{C}$ per year (DHM, 2017). Another study found that a small, but statistically significant, increase in the frequency of hot nights has been observed. In contrast, the annual frequency of "cold" days and nights has decreased significantly since 1960 (McSweeney, New \& Lizcano, 2010). The mountain regions are warming more than the plains (ICIMOD, 2018). The mean annual temperature is expected to continue to increase in Nepal over the remainder of the century. Recent projections indicate that mean annual temperatures could increase by $1.3-1.8^{\circ} \mathrm{C}$ by the $2050 \mathrm{~s}$, with the highest increases in the mountain regions. Along with this, an increase in warm days and nights is predicted (ICIMOD, 2018). With respect to precipitation, the situation is a lot more uncertain. The DHM analysis found that there is no significant trend in precipitation for the country overall; however, district-level data shows a significant decreasing trend in eight districts and an increasing trend in three. Other trends, such as a tendency for decreasing precipitation in all seasons in the high mountains, were not found to be significant (DHM, 2017). Precipitation extremes are found to be increasing (Karki et al., 2017). Recently-developed scenarios suggest that precipitation will increase by $2-6$ per cent by 2030 and by up to 12 per cent by 2050 . From a seasonal perspective, precipitation is likely to increase in all seasons except the premonsoon, when decreases are projected. Premonsoon (March to May) rain is decreasing mainly in the west and increasing in the east. Extremes are also expected to occur more frequently, with an increase in very wet and extremely wet days. Overall, the range of uncertainty in the projections is, however, large that demands flexibility in adaptation planning to address this problem (ICIMOD, 2018).

In Nepal's Himalaya, total estimated ice reserve between 1977 and 2010 has decreased by 29 percent $\left(129 \mathrm{~km}^{3}\right)$. The number of glacier lakes has increased by 11 percent and glaciers recede on an average by $38 \mathrm{~km}^{2}$ per year. Hence, climate change has visible and pronounced impacts on snows and glaciers that are likely to increase the Glacier Lakes Outburst Floods (GLOFs). In Nepal, 21 Glacial Lakes are potentially dangerous. Glacier thinning and retreat in the Himalayas has resulted in the formation of new glacial lakes and the enlargement of existing ones due to the accumulation of melt water behind loosely consolidated end moraine dams. Such lakes are inherently unstable and subject to catastrophic drainage; they are potential sources of danger to people and property in the valleys below them (ICIMOD, 2011). Snow and glacier melt might increase water in Nepal's river system by $5.7 \%$ till 2030 and decrease by $28 \%$ by the end of this century. Nepal has suffered from increased 
frequency of extreme weather events, such as landslides, floods and droughts resulting in the loss of human lives as well as high social and economic costs (MoPE, 2016a). The Economic Impact Assessment of Climate Change in Key Sectors (agriculture, hydropower and water-induced disasters), 2013 has estimated direct cost of current climate variability and extreme events equivalent to 1.5 to 2 percent of current GDP/year (approximately USD 270-360 million/year in 2013 prices) and much higher in extreme years. In the case of hydropower, the model projected lower dry season flows, and thus, lower energy availability. The additional energy generation capacity needed to meet future demand under this scenario, due to climate change, was estimated at 2800 MW by 2050 with an increase in costs of USD 2.6 billion (present value) for the period through to 2050. Overall, the economic costs of climate change in Nepal for these three sectors could be equivalent to $2-3 \%$ of current GDP/year by mid-century (MoSTE, 2013). It is estimated that climate changedriven events could cause losses of $9.9 \%$ of Nepal's annual GDP by 2100 .

There are two ways to respond to climate change: adaptation and mitigation (IPCC, 2001; UNISDR \& UNDP, 2012). Mitigation is an anthropogenic intervention to reduce the sources or enhance the sinks of greenhouse gases, whereas adaptation is an adjustment in natural or human systems in response to actual or expected climatic stimuli or their effects, which moderates harm or exploits beneficial opportunities (IPCC, 2001). Mitigation and adaptation represent two complementary aspects of climate change, which need to be addressed through a holistic approach (Dewulf, 2013).
The integration of climate change issue into sectoral policies has got a top priority among the international and national scholars particularly after the Fifth Assessment Report of the Intergovernmental Panel on Climate Change (2014) which confirmed that each of the last three decades has been successively warmer at the Earth's surface than any preceding decade since 1850 . The period from 1983 to 2012 was likely the warmest 30-year period of the last 1400 years in the Northern Hemisphere (IPCC, 2014). The growing likelihood of a more than $2{ }^{\circ} \mathrm{C}$ warmer world requires better adaptation policy (Di Gregorio et al., 2017) to reduce the current and future effects of climate change. Moreover, IPCC (2014) noted that the longer we wait to take action, the more it will cost and the greater the technological, economic, social and institutional challenges we will face.

In the changing context, the Government of Nepal, with intent to contribute to socioeconomic prosperity by developing climate resilient society, has released a National Climate Change Policy in August 2019 after repealing the 2011 Climate Change Policy (MoFE, 2019). The 2019 policy has the objectives of mainstreaming climate change into relevant policy, strategy, plan and programs, and also mainstreaming gender and social inclusion, including in climate change mitigation and adaptation programs. The policy follows theme-based approach and includes a single policy with a number of non-separated strategies and working policies in 8 thematic areas and 4 cross-cutting areas. Therefore, it is essential to review the current National Climate Change Policy, 2019.

Numerous previous research works concentrated either on adaptation measures or on the policy intervention. For example, 
Ford and Pearce (2010) have only highlighted the essentiality of adaptation measures to reduce the effect of climate change, whereas Regmi and Star (2015) and Ojha, Ghimire, Pain, Nightingale, Khatri and Dhungana (2016) only looked into the policy dimensions during mainstreaming climate change adaptation policies into various sectors. Likewise, Maharjan and Maharjan (2017), Dhungana, Pain, Khatri, Gurung and Ojha (2013) and Mubaya and Mafongoya (2017) have highlighted the crucial role of climate policies and institutions in effective adaptation to climate change in Nepal. Against previous studies, this paper fills in the gaps in existing knowledge, reviewing the mainstreaming of mitigation and adaptation strategies in response to the climate change for different sectors and cross cutting sectors in line with the currently endorsed Nepal's National Climate Change Policy, 2019.

\section{Methodological framework}

This paper is based on desk review of National Climate Change Policy 2019 available in Nepali languages. The text-mining method has been used for the information retrieval and knowledge mining. It analyses the text according to text characters or sentence structure (Scherf, Epple \& Werner, 2005; Regmi \& Shrestha, 2018). While reviewing the prioritized mitigation and adaptation options for different sectors and cross cutting sectors as provisioned by currently endorsed National Climate Change Policy, 2019 by the Government of Nepal, this paper focuses on eight sectors, such as, agriculture, food security and livestock, forest, biodiversity and watershed, water resource and energy, rural and urban settlement, industry', transportation (e-mobility) and physical infrastructure, tourism, natural and cultural heritage, health, drinking water and sanitation, disaster risk reduction and management and four crosscutting sectors such as, gender equity and social inclusion livelihood and governance, empowerment and capacity building, education, knowledge and dissemination and climate finance management.

This paper has followed step by step approach to undertake review of this policy. At first, soft copy of policy documents was collected from the website (www.mofe.gov.np) of Ministry of Forest and Environment. Secondly, the policy document has been grouped into two broad categories, such as policies and institutional structures. Thirdly, the content related to policies has been analyzed in terms of strategies and working policies on mitigation and adaptation by eight sectors and four cross-cutting sectors. Finally, based on the content analysis of policy documents, gaps and constraints in prioritized mitigation and adaptation options for different sectors and cross cutting sectors were identified (Figure 1).

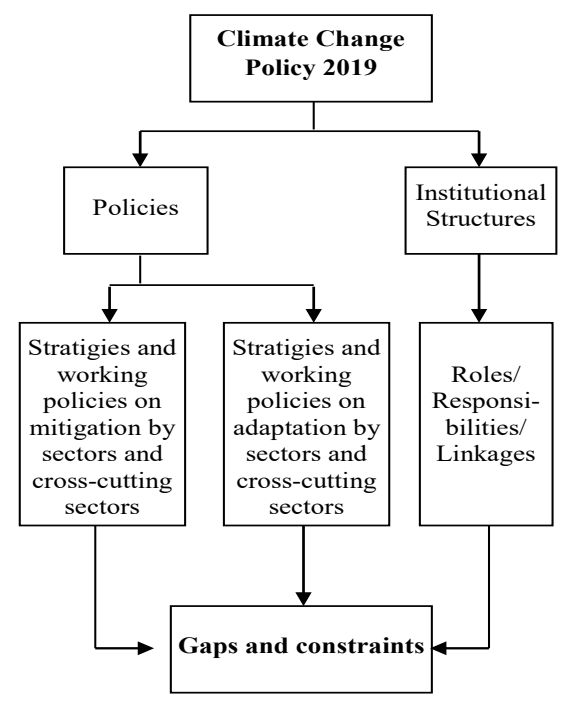

Figure 1: Methodological framework 


\section{Results and discussions}

Nepal has initiated several policy measures to reduce the impact of climate change and increase resiliency through adaptation and mitigation measures. Climate change adaptation and mitigation options have been identified in policy documents of Government of Nepal across the sectors and cross cutting sectors. This section highlights the prioritized mitigation and adaptation strategies identified for different sectors and cross cutting sectors by National Climate Change Policy, 2019.

\section{Strategies on climate change mitigation and adaptation by sectors}

National Climate Change Policy, 2019 has spelled out to launch agro-based adaptation program, identification drought and waterresistant crops, promotion of water saving technologies, climate friendly farming, weather forecasting and crop and livestock insurance. Contrarily, promotion of low carbon emission and energy saving technologies as mitigation options for agriculture, food security and livestock. The policy has identified agro-forestry and provision of Payment for Ecosystem Services (PES) and reduction and management of pests, disease and forest killer as adaptation strategies. An increased storage of forest carbon and REDD+ and CDM can be taken for mitigation option for forest, biodiversity and watershed sector. The policy has made provision of water saving technologies, including water collection ponds and reduction of GLOF risk lowering as the adaptation strategies. At the same time, promotion of renewable energy and energy saving technologies can be viable mitigation measures for water resource and energy sector. Similarly, consideration of climate change risks during land use plan and development of building code as adaptation measures, whereas low emission technologies and green village/city approach are identified as mitigation options for rural and urban settlement sectors. The policy has prioritized formulating and implementing design standards for climate resilient construction of infrastructures for climate change adaptation, such as dams, bridges and river flood control. It also promotes the use of electricity to use it in operating electrical vehicles and mechanical devices as the major thrust to mitigate climate change impacts for industry, transportation (e-mobility) and physical infrastructures sector. Mainstreaming climate friendly tourism approach, management of weather forecasting system, conservation and management of natural and cultural heritage affected by climate change risk and encourage public and private sectors for implementation of climate friendly tourism are emphasized as adaptation strategies. Moreover, the implementation of zero emission system through promotion of renewable energy and promotion of energy saving technologies in tourism sector are prioritized as mitigation strategies for tourism, natural and cultural heritage sector. Focusing on the adaptation strategies to reduce the risk of climate change health, drinking water and sanitation sector, the policy has made provision of preparedness, forecasting and prevention mechanism, conservation of water sources, rainwater harvesting and storage and development of water saved technologies and promotion to convert waste into energy. Development of hazard risk reduction and management system in federal, province and local bodies, development of monitoring, preparedness and forecasting system and rescue, response and reconstruction are 
prioritized adaptation strategies provisioned by this policy for disaster risk reduction and management sector. The details of climate change adaptation and mitigation strategies provisioned by the National Climate Change Policy, 2019 is given in Table 1.

Table 1: Adaptation and mitigation strategies by sectors

\begin{tabular}{|c|c|c|}
\hline Sectors & Adaptation strategies & Mitigation strategies \\
\hline $\begin{array}{l}\text { Agriculture, } \\
\text { food } \\
\text { security } \\
\text { and } \\
\text { livestock }\end{array}$ & $\begin{array}{ll}- & \text { Launch agro-based adaptation program } \\
\text { - } & \text { Identification drought and water-resistant crops } \\
- & \text { Promotion of water saving irrigation } \\
& \text { technologies } \\
- & \text { Climate friendly farming } \\
- & \text { Weather forecasting } \\
- & \text { Crop and livestock insurance }\end{array}$ & $\begin{array}{lll}- & \text { Promotion of low } \\
\text { carbon emission and }\end{array}$ \\
\hline $\begin{array}{l}\text { Forest, } \\
\text { biodiversity } \\
\text { and } \\
\text { watershed }\end{array}$ & 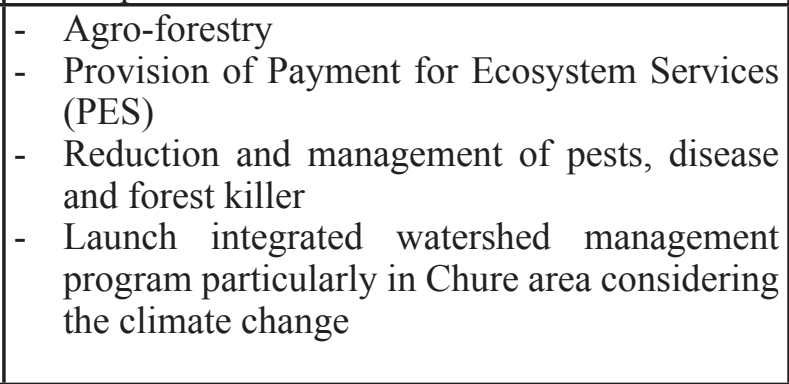 & $\begin{array}{l}\text { - Increase storage } \\
\text { of forest carbon } \\
\text {-REDD+ and CDM } \\
\text { - Equitable distribution } \\
\text { of economic benefit } \\
\text { obtained through } \\
\text { REDD+ and Clean } \\
\text { D e v e lo p m e n t } \\
\text { Mechanism }\end{array}$ \\
\hline $\begin{array}{l}\text { Water } \\
\text { resource and } \\
\text { energy }\end{array}$ & 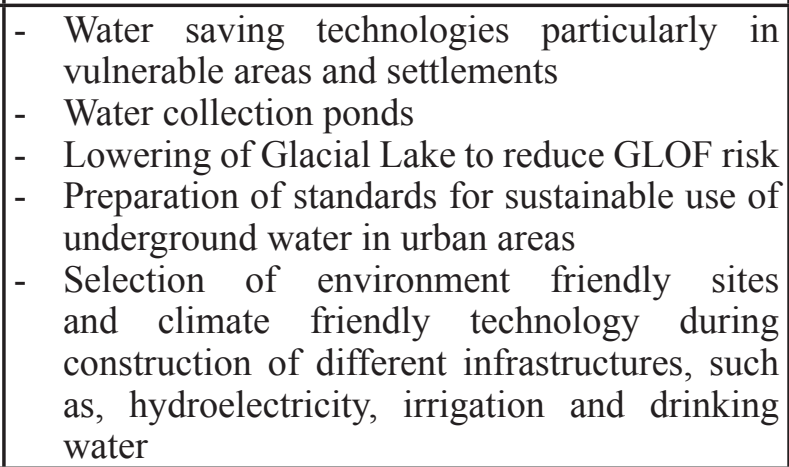 & $\begin{array}{ll}\text { Renewable } & \text { energy } \\
\text { and energy } & \text { saving } \\
\text { technologies } & \end{array}$ \\
\hline $\begin{array}{l}\text { Rural and } \\
\text { Urban } \\
\text { Settlement }\end{array}$ & 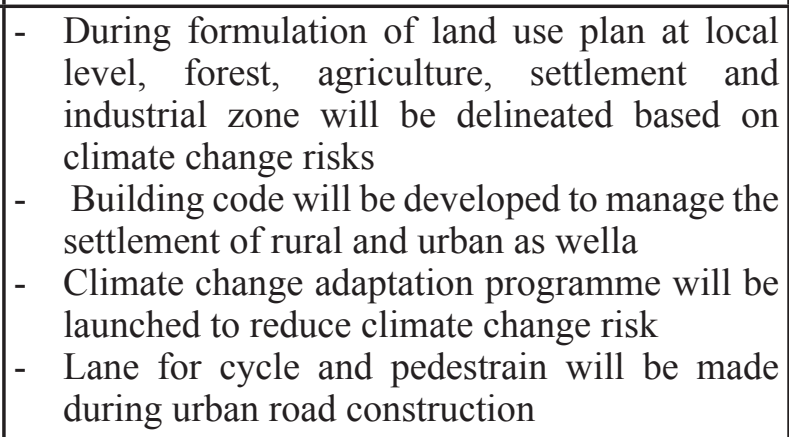 & $\begin{array}{ll}\text { - } & \text { Low emission } \\
& \text { technologies } \\
- & \text { Follow green } \\
& \text { village/city approach } \\
& \\
& \\
\end{array}$ \\
\hline
\end{tabular}




\begin{tabular}{|c|c|c|}
\hline $\begin{array}{l}\text { Industry, } \\
\text { transportation } \\
\text { (E-mobility) } \\
\text { and physical } \\
\text { infrastructures }\end{array}$ & $\begin{array}{l}\text { - Identification of hotspots of greenhouse gas } \\
\text { emission } \\
\text { - Climate friendly technology } \\
\text { - Change in design standard }\end{array}$ & $\begin{array}{l}\text { - Promotion in use of } \\
\text { electricity } \\
\text { - Encourage to use } \\
\text { electrical vehicles }\end{array}$ \\
\hline $\begin{array}{l}\text { Tourism, } \\
\text { natural and } \\
\text { cultural } \\
\text { heritage }\end{array}$ & $\begin{array}{l}\text { - } \begin{array}{l}\text { Mainstreaming climate friendly tourism } \\
\text { approach }\end{array} \\
\text { - } \text { Management of weather forecasting system } \\
\text { - } \begin{array}{l}\text { Conservation and management of natural and } \\
\text { cultural heritage affected by climate change } \\
\text { risk } \\
\text { - Encourage public and private sectors for } \\
\text { implementation of climate friendly tourism }\end{array}\end{array}$ & $\begin{array}{l}\text { - Implementation of } \\
\text { zero emission concept } \\
\text { through promotion } \\
\text { of renewable energy } \\
\text { and energy saving } \\
\text { technologies in } \\
\text { tourism sector }\end{array}$ \\
\hline $\begin{array}{l}\text { Health, } \\
\text { drinking water } \\
\text { and sanitation }\end{array}$ & $\begin{array}{l}\text { - } \begin{array}{l}\text { Preparedness, forecasting and prevention } \\
\text { mechanism }\end{array} \\
\text { - } \begin{array}{l}\text { Conservation of water sources, } \\
\text { - }\end{array} \text { Rainwater harvesting and storage } \\
-\quad \text { Water saving technologies }\end{array}$ & \\
\hline $\begin{array}{l}\text { Disaster risk } \\
\text { reduction and } \\
\text { management }\end{array}$ & $\begin{array}{l}\text { - Development of hazard risk reduction and } \\
\text { management system in federal, province and } \\
\text { local bodies } \\
\text { - Development of monitoring, preparedness and } \\
\text { forecasting system } \\
\text { - } \text { Rescue, response and reconstruction }\end{array}$ & \\
\hline
\end{tabular}

\section{Cross-cutting Sectors}

The National Climate Change Policy, 2019 has made different provisions to address crosscutting issues of climate change, which is given in Table 2.

Table 2: Adaptation and mitigation strategies for cross-cutting sectors

\begin{tabular}{|l|l|}
\hline Cross- Cutting Sectors & Strategies and Working Policies \\
\hline Gender equity and social & - Interest of all community groups will be addressed \\
inclusion. Livelihood and & - Climate resilience livelihood programme \\
Governance & - Local knowledge, skill and technology for adaptation \\
\hline Awareness and Capacity & - Increase access to information and technology \\
Building & - Dissemination through media \\
\hline
\end{tabular}




\begin{tabular}{|c|c|}
\hline $\begin{array}{l}\text { Education, Knowledge and } \\
\text { Dissemination }\end{array}$ & $\begin{array}{l}\text { - Update national database } \\
\text { - Scientific analysis of river, GLOF, wetland and sensitive } \\
\text { ecosystem } \\
\text { - Collection, analysis and dissemination of real time data } \\
\text { - National communication, Nationally Determined } \\
\text { contributions, Adaptation communication and other } \\
\text { reports will be prepared } \\
\text { - Promotion in research and study about climate change } \\
\text { to young }\end{array}$ \\
\hline Climate Finance Management & $\begin{array}{l}\text { - Access and mobilization of bilateral and multilateral } \\
\text { sources } \\
\text { - At least } 80 \% \text { of the climate finance obtained from the } \\
\text { international mechanism will be mobilized at local level } \\
\text { - Climate change budget allocation at all level of } \\
\text { governance and all sectors } \\
\text { - Budget code will be institutionalized with modification } \\
\text { - Private finance mobilization }\end{array}$ \\
\hline
\end{tabular}

\section{Institutional mechanism}

The Ministry of Forest and Environment (MoFE) is designated as the primary agency to coordinate climate change planning in the country. The Climate Change Management Division (CCMD) under the Ministry of Forest and Environment (MoFE) are dedicated to develop policies and actions on climate change (ACT \& Practical Action, 2017). Similarly, the National Planning Commission (NPC) facilitates sectoral coordination and planning processes on climate change related programs at the national/federal level. Ministry of Finance (MoF) is responsible for climate relevant budget allocation and tracking of the expenses.

In order to policy level coordination, the policy has made provision of council at federal level. The responsibility of functional coordination is given to the MoFE. Interministerial coordination committee under the coordination of MoFE led by a different ministries covering different themes agriculture and food security, forests and biodiversity, water resources and energy, climate-induced disasters, public health, and urban settlements and infrastructures, have the potential to play a key role in future cross-sectoral integration and coordination of climate change activities. At the Province level, the role of sectoral ministries who look climate change will be crucial to implement climate change related activities. In federal, province and local level, climate change branch, unit and focal point will take the full responsibility about climate change issue. The policy has provisioned to establish climate change research centre which can have better role in conducting research, technology development and diffusion about climate change mitigation and adaptation. Several non-governmental and communitybased organizations are also engaged in strengthening national and local entities to provide services to the climate vulnerable communities. The climate change networks managed by civil society organizations also contribute to generate and share knowledge on climate change and its impacts. 
The role of different level of government during implementation of National Climate Change Policy 2019 is given in Figure 2.

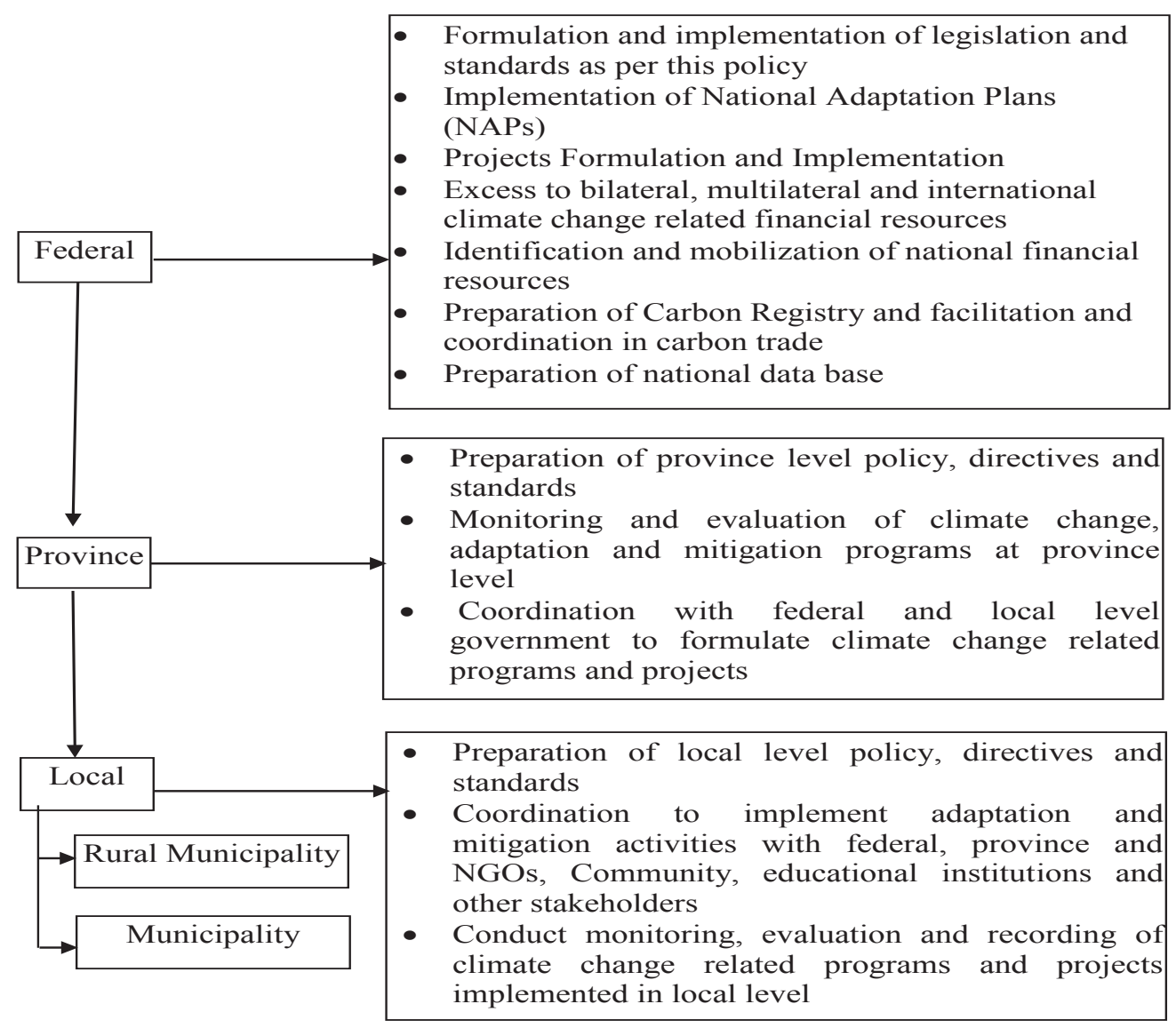

Figure 2: Role of federal, province and local level in policy implementation

\section{Conclusion}

This paper primarily aims at identifying the extent of mainstreaming climate change adaptation and mitigation strategies into different cross-cutting sectors. Nepal has made a significant progress in mainstreaming climate change adaptation issues into different sectoral policies. However, this paper is limited only to review the National Climate Change Policy 2019. This policy is an important policy document, which has for the first-time addressed climate change mitigation and adaptation strategies for different sectors and cross-cutting sectors. This policy for the first time has made provision of institutional set-up representing federal, province and local level. However, the policy formulation and institutional setup needs to be complemented to operate the intent of the relevant policies at all levels of government. Some of the new areas in the 2019 Policy should be added to develop 'payment for ecosystem services', construct pond to collect rain water, cycle lane in urban roads, 
increase carbon stocks, use of renewable technologies and management of climate finance. It has given sole responsibilities of functional coordination to the Ministry of Forest and Environment (MoFE) leaving other ministries as passive partners. This can create incoherence between and among the ministries and departments. At the time of National Climate Change Policy formulation, MoFE plays a key role. However, it is the implementation lie with the local government. It is not clear whether local level government, such as Rural Municipality/Municipality actually had an obligation to implement these provisions or they are established under the Local Government Operation Act (2017) makes them independent from this obligation. The policy formulation and institutional setup alone does not give much expected output unless they are complemented by legislation. Until now, there is not a single legal document in Nepal that exclusively addresses the climate change issue. Therefore, promulgation of Climate Change Act can resolve the problems of climate change in the spirit of this policy.

\section{References}

ACT \& Practical Action (2017). Experience of supporting Nepal's national adaptation plan (NAP) formulation process, An unpublished report, Kathmandu: ACT and Practical Action.

CBS, 2017. National climate change impact survey 2016: A statistical report. Kathmandu: Central Bureau of Statistics.

Dewulf, A. (2013). Contrasting frames in policy debates on climate change adaptation. WIREs Climate Change, (4):321-330. http://dx.doi. org/ 10.1002/ wcc.227.

DHM, (2017). Observed climate trend analysis in the districts and physiographic regions of Nepal (1971-2014). Kathmandu: Department of Hydrology and Meteorology.
Dhungana, H., Pain A., Khatri, D., Gurung, N. \& Ojha, H. (2013). Climate change and rural institutions in Nepal. DIIS Working Paper 16. Copenhagen, Denmark: Danish Institute for International Studies (DIIS).

Di Gregorio, M., et al. (2017). Climate policy integration in the and use sector: mitigation: adaptation and sustainable development linkages. Environmental Science Policy, 67:35-43. Available at www.elsevier.com/ locate/envsci.

Ford, J. D., Pearce, T. (2010). What we know, don't know, and need to know about climate change vulnerability in the western Canadian Arctic. Environ. Res. Lett. 5. http://dx. doi. org/10.1088/1748-765 9326/5/1/014008.

ICIMOD (2011). Glacial lakes and glacial lake outburst floods in Nepal. Kathmandu: ICIMOD.

ICIMOD (2018). Climate change scenarios of Nepal for NAP Process: Main findings. Presentation by Santosh Nepal on behalf of National Adaptation Plan Team. January 17, 2018.

ICIMOD (2018). Status of measurement, reporting, and verification for REDD+ in the Hindu Kush Himalaya. ICIMOD Working Paper 2018/4. Kathmandu: ICIMOD.

IPCC (2001). Climate change: Impacts, adaptation and vulnerability: Summary for policy makers. Geneva: World Meteorological Organisation 〈http://www.ipcc. ch/ ipccreports/tar/wg2/ index.php?Idp $=0$ 〈 [Accessed 3 June 2016].

IPCC (2014). Climate change 2014: Impacts, adaptation and vulnerability. Part A: Global and Sectoral Aspects. Working Group II contribution to 5th Assessment Report of the Intergovernmental Panel on Climate Change. Cambridge University Press. 
IPCC. (2014). Climate change 2014: Synthesis report. Contribution of Working Groups I, II and III to the Fifth Assessment Report of the Intergovernmental Panel on Climate Change [Core Writing Team, R.K. Pachauri and L.A. Meyer (eds.)]. IPCC, Geneva, Switzerland, p. 151.

Karki, R., Hasson, S., Schickhoff, U., Scholten, T., Böhner, J. (2017). Rising Precipitation Extremes across Nepal. Climate 5(4). DOI:10.3390/cli5010004

Maharjan, S. K. \& Maharjan, K. L. (2017). Review of climate policies and roles of institutions in the policy formulation and implementation of adaptation plans and strategies in Nepal. Journal of International Development and Cooperation, 23 (No. 1 \& 2):1-14.

McSweeney, C., New, M. \& Lizcano, G. (2010). The UNDP climate change country profiles improving the accessibility of observed and projected climate information for studies of climate change in developing countries, pp. 157-166. Retrieved from https://www. researchgate.net/publication/234081391

MoFE. (2019). National climate change policy, 2019. Kathmandu: Ministry of Forest and Environment.

MoPE. (2016a). Briefing note on UNFCCC COP 22 and Nepal's key concerns, issues and events. Kathmandu: Ministry of Population and Environment (MoPE).

MoPE. (2016b). Nationally determined contributions. Kathmandu: Ministry of Population and Environment.
MoSTE (2013). Economic impact assessment of cl.imate change in key sectors in Nepal. Kathmandu: Ministry of Science, Technology and Environment (MoSTE), Government of Nepal, Nepal, retrieved from http:// www.asiapacificadapt.net/sites/default/files/ resource/attach/EIAsummary_sharing_finallow-resolution.pdf, on 25 August 2017

MoSTE. (2015). National adaptation plan formulation process. Kathmandu: Ministry of Science, Technology and Environment (MoSTE), Climate Change Management Division.

Mubaya, C. P. \& Mafongoya, P. (2017). The role of institutions in managing local level climate change adaptation in semi-arid Zimbabwe. Climate Risk Management, (16): 93-105. http://dx.doi.org/10.1016/j.crm.2017.03.003.

NPC. (2011).Climate-resilientplanning.(Working Document). Kathmandu: Government of Nepal, National Planning Commission.

Regmi, B. R. \& Star, C. (2015). Exploring the policy environment for mainstreaming community-based adaptation (CBA) in Nepal. International Journal of Climate Change Strategies and Management, 7(4): 423-441.

Scherf, M., Epple, A. \& Werner, T. (2005). The next generation of literature analysis: integration of genomic analysis into text mining. Briefings in bioinformatics, 6(3), 287-297.

UNISDR \& UNDP. (2012). Disaster risk reduction and climate change adaptation in the pacific: An institutional and policy analysis. Suva, Fiji: UNISDR \& UNDP. 